\title{
Application of Steel Pipe Pile Composite Soil Nailing Supporting Combined Foundation Underpinning Technology
}

\author{
Guangbiao Shao* \\ school of civil engineering, Shandong Jianzhu University, Jinan, China \\ * Corresponding Author
}

\begin{abstract}
Power tower is danger when it is located on the top of slope of foundation pit. Composite soil nail technique had been used broadly in pit supporting in different situation except for building and structures nearby. Using foundation underpinning technology, the additional loads of structures can be transferred and bring about stabilization of slope. With the development of underpinning technique, more and more steel pipe pile should be drill near buildings and structures. The excavation of deep foundation pit lead to security risks when power tower near the pit. Based on the composite soil nail technology and foundation underpinning technology, the deep foundation pit supporting method had been proposed. In the method, the steel pipe pile composite soil nailing wall supporting technology had a role of supporting for the vertical excavation of deep foundation pit, simultaneously the foundation of power tower is stabled by underpinning pile and transform the loads into deep soil using steel pipe pile. The engineering example provide better technical reference for similar projects.
\end{abstract}

Keywords-power tower; foundation pit; composite soil nailing; foundation underpinning; steel pipe pile

\section{INTRODUCTION}

With the speeding up of urbanization, all kinds of civil construction and public transportation infrastructure increases rapidly, the development and utilization of underground space is increasing in the city, and some of the engineering construction approaches for high power tower. The foundation pit excavation in underground engineering construction is easy to cause deformation of soil, leading to differential settlement of the power tower, which will lead to the overall stability of the transmission tower and large transmission security hidden danger, even catastrophic consequences.

One power steel tower is near the new municipal engineering excavation. The excavation depth of pit is about $9.0 \mathrm{~m}$ under natural ground. Due to urgency and narrowly limited time schedule, the tower should be protected when foundation pit excavation.The tower foundation generally designed with four independent shallow foundation, two basic tensile, compression of the other two bases.

For guarantee the stability of the foundation pit, composite soil nailing can be performed conveniently. However the deformation of the slope is large when the tower near the pit and induce damages to the steel tower. So the paper take advantage of micro steel pipe pile technology of underpinning reinforcement as supplementary of composite soil nailing supporting [1]. The combination of composite soil nailing and piles of foundation underpinning worked better for pit excavation with protection of power tower and provides a reliable technical reference.

\section{COMPOSITE SOIL NAILING SUPPORTING METHOD}

Soil nailing wall is developed in more than 30 years to maintain stability of foundation pit side or slope soil excavation for a soil retaining structure [2].Generally soil nailing support section as shown in Fig. 1. There are several kinds of components such as soil nail, prestressed anchor, micropiles and concrete surface, water-stopping curtain wall will be added with the higher underground water. By the role of soil nail, the surface layer and the combined action of undisturbed soil, formed on the basis of the active restriction mechanism of complex, has greatly improved the structure of the slope soil strength and resistance to deformation ability, decrease the lateral deformation of soil, enhance the stability of the slope. Supporting effect is mainly set by the length of soil nail, density, soil nail tensile and bending and shear strength of soil, soil nail and the bonding strength, stiffness, soil nailing wall and side wall combined with degree and undisturbed soil properties, the top load and excavation depth factors such as comprehensive decision. One foundation pit completed in 2002, the largest vertical opening of digging depth of $19 \mathrm{~m}$, used the anchor cable composite soil nailing wall for success, marked the soil nailing wall technology has reached a very high level [3].

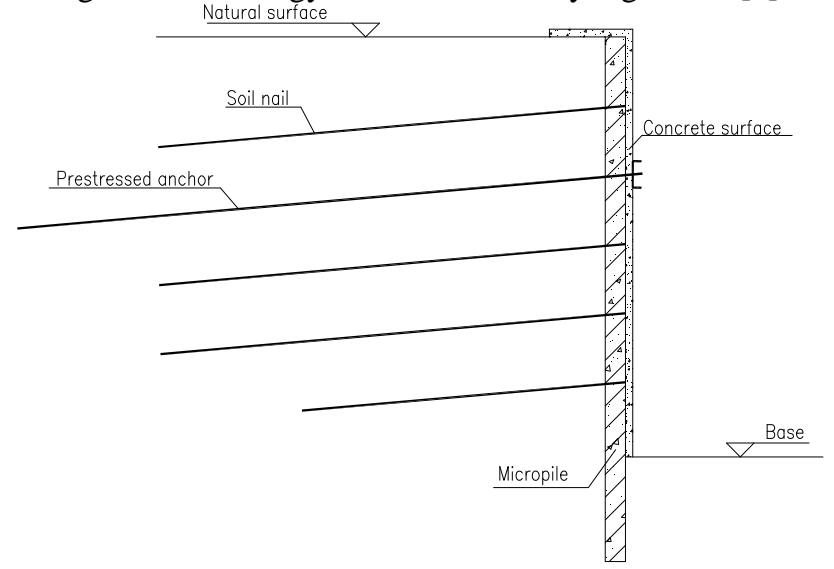

FIGURE I. MICRO PILE COMPOSITE SOIL NAILING PROFILE SKETCH

Soil nailing wall is suitable for the underground water level above or by artificial precipitation after artificial filled soil, cohesive soil and weak cementation sand foundation pit supporting or slope reinforcement[4]. Soil nailing wall should not be used for water rich in silty sand layer, sandy gravel layer and silt soil, the lack of self stabilizing ability 
should not be used for silt and saturated soft soil layer. In order to better control the deformation, anchor should be set in the excavation of the upper.

When no slope space or limited to constructed the scheme of composite soil nailing wall is used. Soil nailing should be stipulated in the design of stratified excavation depth according to the operation sequence of construction, at the completion of the upper surface of soil nailing and shotcrete, before may not be on to the next layer depth of excavation.

Steel pipe pile composite soil nailing wall has flexible, wide applicable range, low cost, short construction period and the characteristics of safe and reliable. In practical engineering, the composite soil nailing wall in all kinds of technology according to the organic combination of engineering need to be flexible, so that the construction is simple, economic and reasonable, comprehensive performance is outstanding, and deformation and the overall stability of the slope can meet the requirements[5].

Steel pipe pile stiffness and strength of composite function. The stiffness and strength, the greater the composite support system, the more have pile anchor. Failure morphology and mechanical properties of the support, can be used for the analysis of the principle of the combined bolting; The smaller, the closer to the soil nailing wall, can be reference to the design theory of soil nail wall. In order to make the micro pile can play a role of a whole, usually at the top of the pile setting crown beam. In general, the greater the stiffness of pile and composite soil nailing wall effect. Steel pipe pile composite soil nailing wall, usually are not destroyed by shear, but washed curved or between sliding out from the pile soil. Although there are many kinds of practice of micro pile, the pile stiffness difference, the research of stiffness of pile impact on the soil nailing wall needed.

Steel pipe pile composite soil nailing wall failure mode has two kinds: (1)Similar to the mixing pile composite soil nailing wall shear instability destruction, pile was cut, soil nail bent, pull out or surface. (2) Mainly for soil shear failure, after the collapse of earthwork from pile, micro pile is not damaged, or destroyed by collapsed earthwork shearing break. When steel pipe pile stiffness is bigger, which can significantly reduce the levels of slope displacement and ground settlement, therefor stiffness of pipe is important point in the design work.

\section{FOUNDATION UNDERPINNING TECHNIQUE USING STEEL PIPE PILE}

Foundation underpinning is the foundation of original structure reinforcement and change, to improve the basic work state, such as uneven settlement, the structure of the building when the load increases, etc. Power tower generally adopts the cast-in-place reinforced concrete shallow foundation. Additional load are appeared near the excavation and bad for foundation pit slope stability. A certain corner tower foundation arrangement as shown in Fig. 2. With the help of foundation underpinning technology, the additional loads can transfer to deeper soil layer and at the same time is conducive to the settlement and deformation control of the transmission tower foundation.

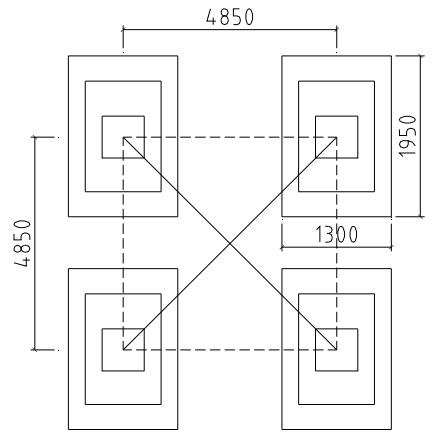

FIGURE II. THE PLAN OF POWER TOWER FOUNDATION

Some difficulties had existed in power tower foundation underpinning: (1) under the operation of the transmission tower operation and high safety requirements, large-scale construction equipment operation is highly restricted; (2) reducing as far as possible on the original foundation and the vibration of the foundation, to avoid affect the running of the transmission tower. Therefore foundation underpinning of tower should be given sufficient consideration of construction technology and machine of pile type selected to meet the above conditions.

Steel pipe pile technology on the basis of the transmission tower in the research focus and get more engineering application in recent years [6, 7]. The steel pipe pile is a kind of small diameter pile, using pressure grouting process machinery into a hole, the diameter is less than $350 \mathrm{~mm}$, generally pile length not exceed $30 \mathrm{~m}$.

Fig. 3 is schematic diagram of transmission tower foundation underpinning by steel pipe pile, pile top and planting bar foundation through the new cap and achieve effective connection.

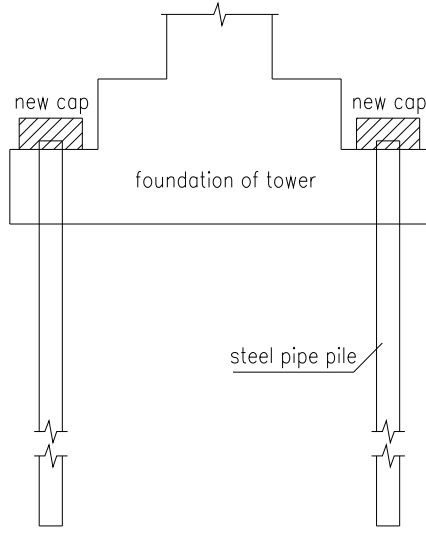

FIGURE III. FOUNDATION UNDERPINNING WITH MICRO-PILE

So when power tower foundation underpinning by smalldiameter steel pipe pile can better solve the above problems: (1) micro pile construction machinery is simple, can use small drill to pore-creating and strong adaptability to the surrounding environment; (2) the pile hole diameter is small, pore forming process on the original foundation and foundation soil almost do not produce additional stress, noise and vibration caused by the construction is very small, and does not affect the normal use of transmission tower [8,9]; (3) Upper load force can be downward clearly. Meanwhile the soil mechanical characteristics can be improved through the secondary high pressure grouting, which can effectively improve the bearing capacity of single pile and the ability to resist overturning.

When underpinning using root pile, pile can be thought of not effect during construction. But after the underpinning 
construction, base even produce minimal subsidence, micro pile will force quickly and take part of the structure load, at the same time reduce basal force on soil layer. If structure continues to sink, micro pile of load will increase gradually, until all the load borne by the micro pile.

Because of the tiny pile diameter is small, bearing capacity of friction pile can be calculated only when all pile in the soil. The compressive bearing capacity of single pile can be calculated by Equation 1[10].

$$
P_{u p}=U \sum_{i=1}^{n} L_{i} q_{s i k}
$$

In the equation: $U$ is the circumference of pile body; $L_{i}$ is the depth of the ith layer of soil; $q_{s i k}$ is the limit of soil lateral resistance standard.

\section{DESIGN EXAMPLE}

\section{A. Engineering Geological Profile}

According to the survey report, the proposed site belongs to the alluvial plain of sand silted geomorphic unit, the soil layer as shown in Table I.

TABLE I. SOIL PARAMETERS

\begin{tabular}{|c|c|c|c|}
\hline Soil layer & $\begin{array}{c}\text { Average } \\
\text { Thickness/ } \mathbf{~ m}\end{array}$ & $\begin{array}{c}\text { Natural Weight/ } \\
\mathbf{k n} / \mathbf{m} 3\end{array}$ & $\boldsymbol{q}_{\text {sik }} / \mathbf{k P a}$ \\
\hline grain filling & 1.15 & 17.8 & 20 \\
\hline clay & 4.47 & 18.2 & 55 \\
\hline silty clay & 5.21 & 18.4 & 70 \\
\hline sandy silt & 4.78 & 18.8 & 76 \\
\hline
\end{tabular}

\section{B. Tower Foundation Underpinning Design}

According to Equation (1) and soil parameters, pile diameter is designed for $180 \mathrm{~mm}$, built-in $108 \mathrm{~mm}$ diameter, wall thickness $5 \mathrm{~mm}$ steel tube, when the effective pile length is $15 \mathrm{~m}$, the bearing capacity characteristic value of up to $194 \mathrm{kN}$, design value of single pile bearing capacity characteristic is $180 \mathrm{kN}$. And basis weight of the upper structure load calculation, each independent foundation base load about $1032 \mathrm{kN}$, so 6 steel pipe piles should be arranged. Pile arrangement and local section as shown in Fig.4, due to a quarter of the independent foundation is located inside the tower frame, for the construction inconvenience and considering asymmetric effect, set up five straight pile, two inclined pile, total of 7 piles, tower based load effectively to ensure that the lower soil.

When underpinning using root pile, pile can be thought of not effect during construction. But after the underpinning construction, base even produce minimal subsidence, micro pile will force quickly and take part of the structure load, at the same time reduce basal force on soil layer. If structure continues to sink, micro pile of load will increase gradually, until all the load borne by the micro pile.

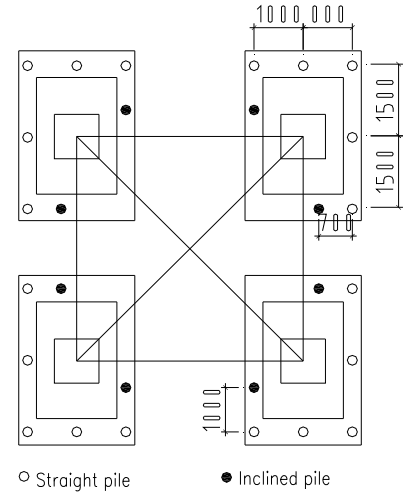

FIGURE IV. POWER TOWER FOUNDATION UNDERPINNING PLAN

\section{Composite Soil Nailing Supporting Design}

In view of the construction site restrictions, vertical slope excavation of foundation pit be adopted, using steel pipe pile composite soil nailing wall supporting scheme, micro pile diameter $180 \mathrm{~mm}$, same as the underpinning pile body material. Miniature pile built-in depth of $2.0 \mathrm{~m}, 0.75 \mathrm{~m}$ horizontal spacing; Supporting profile setting anchor 2 rows and 3 rows soil nailing, their horizontal spacing of $1.5 \mathrm{~m}$, and the horizontal angle of $15 \mathrm{o}$. Anchor need to set up the waist beam tension to control the deformation of the foundation pit wall. Supporting design section as shown in Fig. 5.

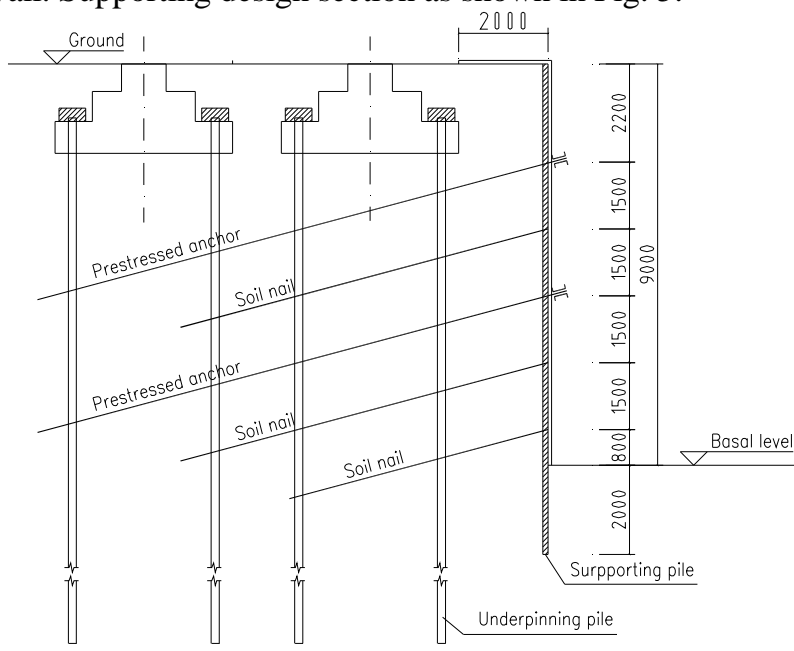

FIGURE V. UNDERPINNING TECHNOLOGY COMBINED COMPOSITE SOIL NAILING SUPPORT SECTION

The stability of composite soil nailing wall integral calculation is not consider tower loads and its overall stability coefficient are more than 1.3, satisfied with the relevant specification requirements. In the subsequent engineering construction, the upgraded drill rigs are used for boring for underpinning pile and supporting pile, which provides guarantee to finish on time for the municipal engineering.

\section{CONCLUSIONS}

Based on steel pipe pile composite soil nailing wall supporting and foundation underpinning technology, the power tower foundation near deep foundation pit had been protected successfully.

Some In design scheme: (1) the foundation pit supporting design, fully considering the advanced supporting effect of steel pipe pile, using of composite soil nailing wall technology, guarantee the stability of the foundation pit 
slope. (2)the foundation underpinning design make full use of characteristics of micro pile, such as construction space requirements is low, the impact on both the structure characteristics of bearing capacity and clear, ensure the smooth implementation of the foundation underpinning, have created favorable conditions for the foundation pit excavation.

\section{ACKNOWLEDGMENT}

This work was financially supported by National Natural Science Foundation of China (51008183).

\section{REFERENCES}

[1] Yugu Huang and Fei Zhou, “The application of the micro steel pipe piles in foundation reinforcement engineering," Sichuan Architecture, vol.26, 2006, pp. 76-77.

[2] Zhiyin Yang, Jun Zhang and Kaixu Wang, "Development of composite soil nailing walls,” Chinese J. Geot. Eng., vol.27, 2005, pp. 153-156.

[3] Shenduo Feng, Zhiyin Yang, Kai-xu Wang and Bin Xu, "Complex deep foundation pit technology of successful application of composite soil nailing wall”, Industrial Construction, vol.33(z2), 2004, pp.229-235.

[4] Lizhou Chen, Pinhui Zhuang and Zhimin He, "Deformation comparison between composite soil nailing wall and soil nailing wall.' Construction Technology, vol.30, 2001, pp.26-27.

[5] Lingbing Yi, Qian Wang, Xiaolong Chen, "The design and application of miniature pile composite soil nailing wall in the deep cutting slope supporting”, Henan Science, vol.32, 2014, pp.20152062.

[6] Rongzhen Su, Weifeng Zheng, Xianglong Lu and Yongfeng Chen, "Experimental on uplifting characters of micropiles of tower foundations in soft soils," Electric power construction, vol.29, 2008, pp. 23-25.

[7] Daping Liu, "Transmission line analysis of the application of micropile foundation,” Anhui Electric Power, vol.26, 2009, pp. 35-38.

[8] Yong Qu, "Numerical analysis of micropile foundation for transmission line.” Electric Power Construction, vol.32, 2011, pp.5961.

[9] Rongzhong Du, "Discussion on application of micro-pile in transmission line.” HongShui River, vol.30, 2011, pp.79-82.

[10] JGJ94-2008, Technical Code for Building Pile Foundations [s]. Beijing: China building industry press, 2008. 